\title{
Subzygomatic and infraorbital approaches for maxillary nerve blockade in cats' cadaver
}

\author{
José Ricardo Herrera Becerra ${ }^{1}$ Tainor de Mesquita Tisotti ${ }^{1}$ Maria Eduarda Baier ${ }^{1}$ \\ Ronaldo Viana Leite-Filho' ${ }^{1}$ Verônica Santos Mombach ${ }^{1}$ \\ Fernanda Vieira Amorim da $\operatorname{Costa}^{1}$ Eduardo Raposo Monteiro ${ }^{2 *}$
}

${ }^{1}$ Universidade Federal do Rio Grande do Sul (UFRGS), Porto Alegre, RS, Brasil.

${ }^{2}$ Departamento de Medicina Animal, Faculdade de Veterinária, Universidade Federal do Rio Grande do Sul (UFRGS), 91540.000, Porto Alegre, RS, Brasil. E-mail: eduardo.monteiro@ufrgs.br. "Corresponding author.

\begin{abstract}
This study compared the accuracy of dye placement on the maxillary nerve by using the percutaneous subzigomatic (SBZ) and infraorbitary (IO) approaches in cats' cadavers. A second aim was to compare the accuracy of dye placement on the maxillary nerve between different untrained anesthetists. This was a prospective, randomized, blinded study, performed in 40 heads obtained from feline cadavers. Three veterinarians $(A, B$ and $C$ ) with no previous experience with the IO approach performed the experiments. The SBZ approach was randomly performed on one side of the head and the IO approach was performed in the contralateral side of the same head. For each approach, $0.2 m l$ of $1 \%$ methylene blue dye was injected. Scores for length of nerve staining were as follows: 0 (failure), no staining; 1 (moderate), <6mm of nerve stained; and 2 (ideal), $\geq 6 \mathrm{~mm}$ of nerve stained. Median scores (interquartile range) for the SBZ and IO approaches were 2.0 (0.3-2.0) and 1.0 (0.0-2.0), respectively. Scores for length of nerve staining were higher with the SBZ approach than the IO approach (P=0.016). Considering the scores for both the SBZ and IO approaches, there was a significant difference among the three veterinarians $(P=0.002)$. Results of this study do not support the IO approach to perform a maxillary nerve block in cats. A greater accuracy of methylene blue dye placement was observed with the SBZ approach. A variable accuracy may exist between different veterinarians when performing a maxillary nerve block employing the $S B Z$ and IO techniques in cats.

Key words: dental anesthesia, cats, maxillary nerve, methylene blue, nerve block.
\end{abstract}

Abordagens subzigomática e infraorbitária para o

bloqueio do nervo maxilar em cadáver de gatos

RESUMO: $O$ objetivo deste estudo foi comparar o acesso do nervo maxilar pela abordagem subzigomática (SBZ) com a abordagem pelo forame infraorbitário (IO) em peças anatomicas de gatos utilizando o corante azul de metileno. Um segundo objetivo foi comparar a acurácia na coloração do nervo maxilar com o azul de metileno entre diferentes anestesistas que não receberam treinamento prévio. Este estudo foi prospectivo, randomizado, cego, realizado em 40 peças anatômicas de cabeças de gatos. Três veterinários (A, $B$ e $C$ ), sem experiência prévia da abordagem $I O$, realizaram o experimento. A abordagem SBZ foi aleatoriamente realizada em um dos lados da cabeça e a abordagem IO foi realizada no lado contralateral da mesma peça anatômica. Para cada abordagem, utilizou-se 0,2mL do corante azul de metileno 1\%. Classificou-se o escore de coloração baseado no comprimento do nervo maxilar corado pelo azul de metileno conforme a escala: 0 (falha da técnica), sem coloração; 1 (moderado), <6mm de coloração do nervo maxilar; 2 (ideal), $\geq 6 \mathrm{~mm}$ de coloração do nervo maxilar. As medianas (intervalo interquartil) para as abordagens SBZ e IO (dados de todos os veterinários juntos) foram respectivamente 2,0 (0,3-2,0) e 1,0 (0,0-2,0). A abordagem SBZ foi associada a um escore de coloração, significativamente, maior do que a abordagem IO $(P=0,016)$. Considerando os escores de ambas abordagens (SBZ e IO), houve diferença significativa nos escores de coloração do nervo maxilar entre os três veterinários anestesistas ( $P=0,002)$. Os resultados deste estudo não sustentam a utilização da abordagem IO para a realização do bloqueio maxilar em gatos. Uma melhor acurácia na coloração do nervo maxilar com o azul de metileno foi observada com a abordagem SBZ. A acurácia da técnica pode variar quando as abordagens SBZ e IO são realizadas por veterinários diferentes, com o objetivo de se obter o bloqueio do nervo maxilar.

Palavras-chave: anestesia odontológica, gatos, nervo maxilar, azul de metileno, bloqueio de nervo.

\section{INTRODUCTION}

Local anesthetics prevent the generation and transmission of action potentials by reversibly blocking voltage-gated sodium channels in the neuronal cell membrane (BECKER \& REED, 2012). Loco regional anesthetic techniques have been used to provide the intraoperative anti-nociceptive 
component of balanced anesthetic protocols, thereby decreasing the dose of general anesthetics needed for maintenance of anesthesia (PERALTA et al., 2015).

There are several local anesthetic techniques described in dogs and cats with the aim of providing analgesia for specific regions of the head, including the oral cavity (FUTEMA et al., 2002; BARDELL et al., 2010; VISCASILLAS et al., 2013). Maxillary nerve is a branch of the trigeminal, which provides sensory information to the skin of the upper lips and nostrils, as well as the soft and hard palate, upper teeth, gingiva and maxilla (DELLMANN \& MCCLURE, 2008; PERRY et al., 2015). Therefore, maxillary nerve blockade provides anesthesia for selected procedures such as rhinoscopy, maxillectomy and upper teeth extractions (CREMER et al., 2013).

There are a few techniques described for performing a maxillary nerve block in dogs and cats (DUKE, 2000; ROCHETTE, 2005; KLAUMANN, 2013; VISCASILLAS et al., 2013). The most common used techniques for this purpose are the percutaneous subzigomatic (SBZ) and the intraoral approaches. In a recent study in canine cadavers, an infraorbitary (IO) approach was described using an over-the-needle catheter that was introduced into the IO foramen and advanced toward the maxillary nerve (VISCASILLAS et al., 2013). In this latter study, a higher percentage of maxillary nerve staining with methylene blue dye was reported after the IO approach when compared with the SBZ approach (64.9\% versus 21.6\%) (VISCASILLAS et al., 2013). To our knowledge, the IO approach of the maxillary nerve has not been described in cats. The primary aim of this study was to compare the spread of methylene blue dye using two techniques (IO and SBZ approaches) of maxillary nerve blockade in cat cadavers. The hypothesis was that a greater percentage of success would be obtained with the IO than the SBZ approach. A secondary aim was to compare the spread of methylene blue dye on the maxillary nerve between different untrained anesthetists.

\section{MATERIALS AND METHODS}

Forty heads obtained from feline cadavers were used. Cadavers were from cats admitted to the Veterinary Teaching Hospital, after natural death or euthanasia due to reasons unrelated to the study. On all occasions, the owners decided to discard cats' bodies. Heads were separated from their bodies and were stored under refrigeration $\left(<4^{\circ} \mathrm{C}\right)$ until the experiments were performed (within 1 to 5 days after the death). Exclusion criteria were: brachycephalic breeds, age less than six months, head trauma and skulls with evidence of bone pathology.
This was a prospective, randomized, blinded study. Three veterinarians with no previous experience with the IO approach performed the experiments. Veterinarians A and B were enrolled in a residency program in veterinary anesthesiology, which had approximately one year of experience in clinical practice. Veterinarian $\mathrm{C}$ had completed the residency program and had approximately three years of experience in clinical practice. Prior to the beginning of the study, both the SBZ and IO approaches were standardized among the three veterinarians using a cat skull to help identifying anatomical landmarks.

On each head, the SBZ approach was performed on one side (left or right) and the IO approach was performed in the contralateral side of the same head. The side of the head allocated for each approach was chosen randomly. For each approach, $1 \mathrm{~mL}$ plastic syringes filled with $0.2 \mathrm{~mL}$ of $1 \%$ methylene blue dye were used.

For the SBZ technique, a $22 \mathrm{G} \times 1$ inch hypodermic needle was inserted perpendicular to the skin in a point located between the caudal margin of the maxilla and the cranial border of the jaw body, ventral to the rostral portion of the zygomatic arch. The needle was advanced into the pterygopalatine fossa and, when it was considered by the veterinarian to be in close proximity to the maxillary nerve, injection of methylene blue dye was performed (Figure 1). For the IO approach, the upper lip was elevated and the $\mathrm{IO}$ foramen was palpated dorsal to the first premolar tooth. A $22 \mathrm{G} \times 25 \mathrm{~mm}$ over-the-needle catheter was introduced 3 to $4 \mathrm{~mm}$ into the $\mathrm{IO}$ foramen in a rostrocaudal direction, parallel to the occlusion of the dental arches. The catheter was then advanced with the stylet held in place. When the catheter was entirely introduced into the IO canal, the stylet was removed, and injection of methylene blue dye was performed (Figure 2). On all occasions, methylene blue dye was injected with the head in a latero-lateral position (i.e. with the side to be blocked uppermost). Before each injection, negative aspiration of blood was confirmed and methylene blue dye was injected without resistance as a fast bolus injection ( $<2$ seconds). The veterinarian performing the experiment subjectively evaluated lack of resistance to injection.

After both techniques had been completed, a fourth veterinarian performed the dissections on each side of the head to allow visualization of the pterygopalatine fossa and the maxillary nerve. Briefly, using scalpel and anatomic forceps, the skin over the fossa, maxilla and mandible, and muscles from the temporomandibular joint were dissected. The ramus of the mandible was cut just below de condylar process using a pruner, and the mandible 


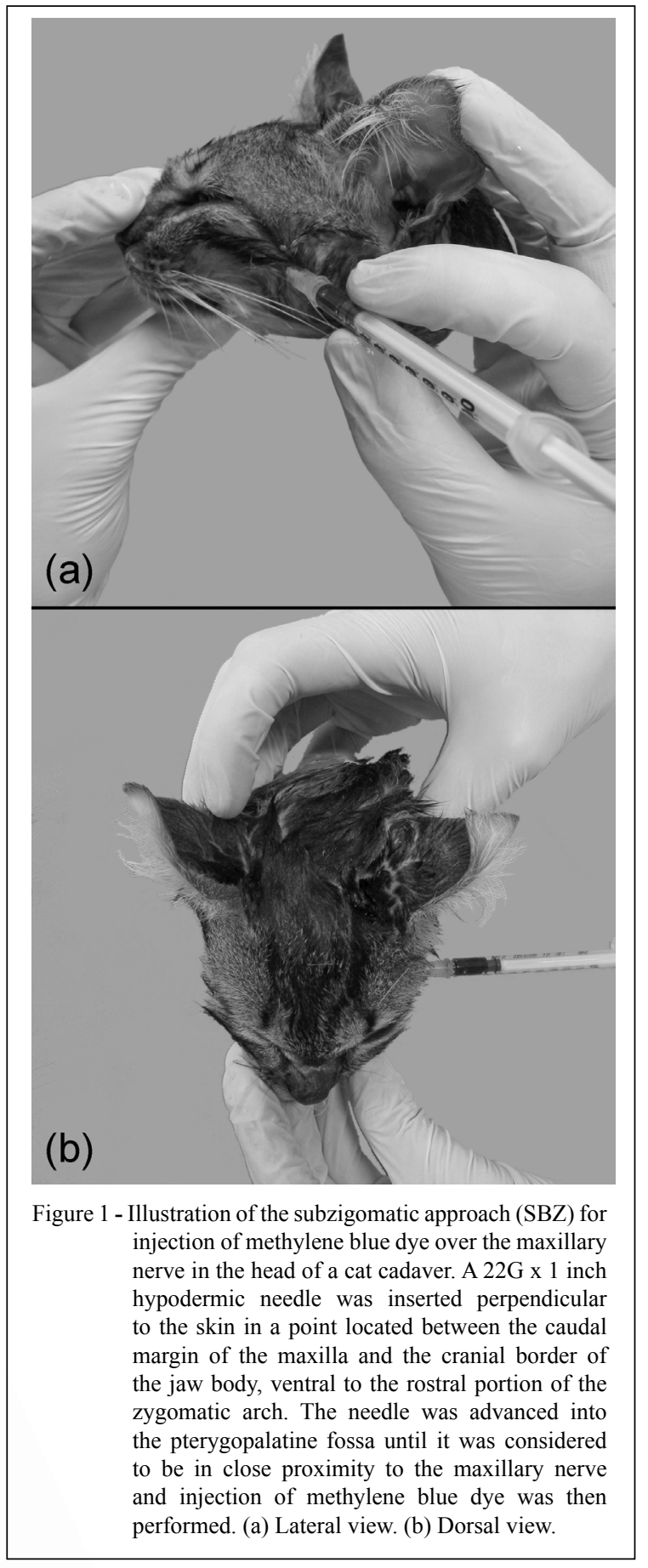

taken off. Muscles over the zygomatic arch were also dissected, and the arch was cut just at the emergence of the zygomatic and temporal processes on each side. The muscles and connective tissue in the fossa were then carefully dissected in order to expose the nerves from as close as possible of the foramen rotundum

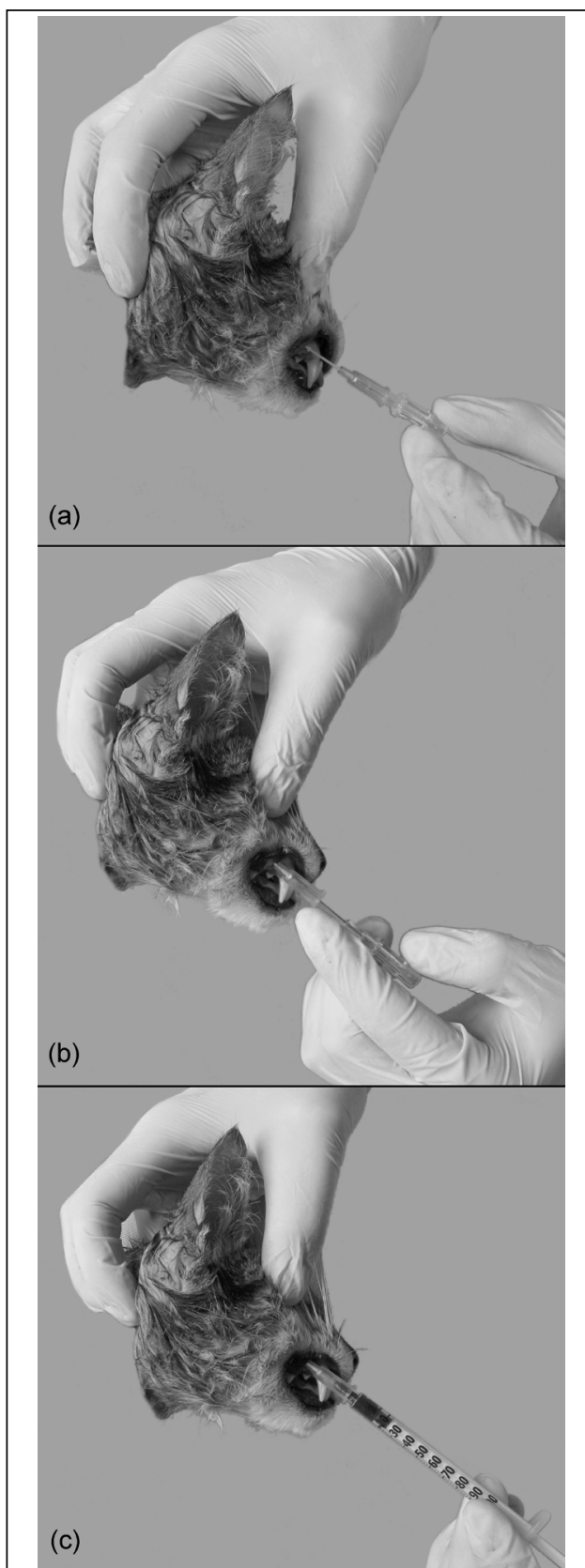

Figure 2 - Illustration of the infraorbital foramen approach (IO) for injection of methylene blue dye over the maxillary nerve in the head of a cat cadaver (lateral view). (a) The upper lip was elevated and the IO foramen was palpated dorsal to the first premolar tooth. A $22 \mathrm{G} \times 25 \mathrm{~mm}$ over-theneedle catheter was introduced 3 to $4 \mathrm{~mm}$ into the IO foramen in a rostrocaudal direction, parallel to the occlusion of the dental arches. (b) The catheter was advanced with the stylet held in place. (c) When the catheter was entirely introduced into the IO canal, the stylet was removed, and injection of methylene blue dye was performed.

Ciência Rural, v.48, n.4, 2018. 
to the infraorbital, sphenopalatine and lesser palatine foramina. The veterinarian that performed the dissections was unaware of what technique had been used and assigned a score for length of nerve staining as follows: 0 (failure), no staining; 1 (moderate), $<6 \mathrm{~mm}$ of nerve stained; and 2 (ideal), $\geq 6 \mathrm{~mm}$ of nerve stained. Data were analyzed using a General Linear Model performed with SPSS version 18. First, a two-way repeated measures ANOVA was used to investigate the effect of approach (SBZ or IO), veterinarian $(\mathrm{A}, \mathrm{B}$ and $\mathrm{C})$ and their interaction on the scores for length of nerve staining. In the event of a significant effect of veterinarian, a Bonferroni test was performed to compare the scores among the three veterinarians. A $\mathrm{P}$ value of $<0.05$ was considered statistically significant.

\section{RESULTS}

Median scores (interquartile range) for length of nerve staining (polled data from all veterinarians) were $2.0(0.3-2.0)$ and $1.0(0.0-2.0)$ for the SBZ and IO approaches, respectively. The SBZ approach was associated with a higher score for length of nerve staining than the IO approach $(\mathrm{P}=0.016)$ (Table 1).

Veterinarians $\mathrm{A}, \mathrm{B}$ and $\mathrm{C}$ performed 40, 22 and 18 approaches in 20,11 and 9 heads, respectively. Scores from each veterinarian according to the extension of maxillary nerve staining are summarized in table 2 . There was a significant effect of veterinarian on the scores for length of nerve staining $(\mathrm{P}=0.002)$. Considering the scores from both the SBZ and IO approaches, veterinarian $\mathrm{B}$ had lower scores than veterinarians $\mathrm{A}$ and $\mathrm{C}(\mathrm{P}=0.011$ and $\mathrm{P}=0.004$, respectively). There was no significant difference between scores from veterinarians $\mathrm{A}$ and $\mathrm{C}(\mathrm{P}=1.00)$.

When no staining of the maxillary nerve was observed after performing the IO approach, deposition

Table 1 - Median (interquartile range) scores for each veterinarian according to the extension of maxillary nerve staining by methylene blue dye in cadaver of cats.

\begin{tabular}{lll}
\hline Veterinarian & SBZ & IO \\
\hline $\mathrm{A}$ & $2.0(1.0-2.0)$ & $1.0(0.0-2.0)$ \\
$\mathrm{B}$ & $0.0(0.0-2.0)^{*}$ & $0.0(0.0-0.0)^{*}$ \\
$\mathrm{C}$ & $2.0(1.5-2.0)$ & $2.0(0.0-2.0)$ \\
$\mathrm{A}+\mathrm{B}+\mathrm{C}$ & $2.0(0.3-2.0)^{\dagger}$ & $1.0(0.0-2.0)^{\dagger}$ \\
${ }^{*}$ Within a column, & significant difference compared to \\
veterinarians A and C $(\mathrm{P}<0.05)$. & ${ }^{\dagger}$ Within a row, significant \\
difference between the $\mathrm{IO}$ and $\mathrm{SBZ}$ approaches $(\mathrm{P}<0.05) . \mathrm{SBZ}=$ \\
subzigomatic approach; IO = infraorbital approach.
\end{tabular}

of methylene blue dye was reported on infraorbitary fat, on the infraorbitary nerve or adjacent structures. In one head, there was evidence of methylene blue dye deposition on the sclera and cornea on the same side of the head which the IO approach was performed. When no staining of the maxillary nerve was observed after performing the SBZ approach, deposition of methylene blue dye was reported on infraorbitary fat or the lateral rectus muscle (medial to the maxillary nerve).

\section{DISCUSSION}

The hypothesis of this study was rejected. Overall, the SBZ approach was associated with higher scores of maxillary nerve staining than the IO approach. A score of 2 ( $\geq 6 \mathrm{~mm}$ of nerve staining) was observed in $62.5 \%$ of the SBZ techniques performed, compared to $37.5 \%$ of the IO approach. These findings differ from a similar study performed in cadavers of dogs (VISCASILLAS et al., 2013). In this previous study, a higher percentage of maxillary nerve staining $\geq 6 \mathrm{~mm}$ was observed following the IO than the SBZ approach (64.9\% versus $21.6 \%$, respectively) (VISCASILLAS et al., 2013). The authors believe that discrepancies between the two species were due to anatomical differences between the skulls of dogs and cats. In domestic cats, the IO canal is short (DELLMANN \& MCCLURE, 2008; HUDSON, 2010) and indeed it has been reported that cats actually lack a true IO canal (GROSS et al., 2000). This anatomical feature allows a wide variety of angulations when introducing the catheter into the IO foramen. Conversely, the IO canal is longer in dogs than cats and serves as an anatomical reference to guide the catheter through the IO foramen towards the maxillary nerve (GIOSO \& CARVALHO, 2005; HUDSON, 2010). These anatomical differences may explain, at least in part, the lower success rate in staining the maxillary nerve following the IO approach in cats as compared to dogs. Results of this study supports that the efficacy of a locoregional anesthetic technique in dogs should not be extrapolated to cats. Moreover, despite that the SBZ approach was more effective than the IO approach in the present study, further research is warranted to access the efficacy of each technique in the clinical setting.

In the present study, veterinarians A and $\mathrm{C}$ had significantly higher scores of maxillary nerve staining than veterinarian $\mathrm{B}$. Higher success rate for veterinarian $\mathrm{C}$ may be attributable to a longer professional experience in the field of veterinary anesthesiology than veterinarian B (3 years versus 1 year). Conversely, veterinarians A and B had nearly 
Table 2 - Distribution of attempts for each veterinarian according to the length of maxillary nerve staining by methylene blue dye in cadaver of cats. Description of scores are as follows: 0 (failure), no staining; 1 (moderate), $<6 \mathrm{~mm}$ of nerve stained; and 2 (ideal), $\geq 6 \mathrm{~mm}$ of nerve stained.

\begin{tabular}{lcccccccc}
\hline & & & & & & & & \\
& & & & & & & & \\
& & & & & & \\
Veterinarian & $\mathrm{A}$ & $\mathrm{B}$ & $\mathrm{C}$ & $\mathrm{A}+\mathrm{B}+\mathrm{C}$ & $\mathrm{A}$ & $\mathrm{B}$ & $\mathrm{C}$ & $\mathrm{A}+\mathrm{B}+\mathrm{C}$ \\
Score 2 & $13(65.0)$ & $5(45.5)$ & $7(77.8)$ & $25(62.5)$ & $9(45.0)$ & $1(9.1 \%)$ & $5(55.6)$ & $15(37.5)$ \\
Score 1 & $3(15.0)$ & $0(0.0 \%)$ & $2(22.2)$ & $5(12.5)$ & $4(20.0)$ & $1(9.1 \%)$ & $1(11.1)$ & $6(15.0)$ \\
Score 0 & $4(20 \%)$ & $6(54.5)$ & $0(0.0 \%)$ & $10(25.0)$ & $7(35.0)$ & $9(81.8)$ & $3(33.3)$ & $19(47.5)$ \\
Total & 20 & 11 & 9 & 40 & 20 & 11 & 9 & 40 \\
\hline
\end{tabular}

$\mathrm{SBZ}=$ subzigomatic approach; $\mathrm{IO}=$ infraorbital approach.

the same professional experience. One reason for the higher scores observed for veterinarian A might be the greater number of injections performed when compared with veterinarian B (40 injections in 20 heads versus 22 injections in 11 heads, respectively), which may have resulted in greater learning experience by veterinarian A. However, this statement is speculative and the differences in the number of approaches among the three veterinarians may actually be a source of bias in the present study. A better design for the study would be an equal distribution of injections for each veterinarian.

For the IO technique, an over-the-needle catheter rather than a hypodermic needle was used. Advancing a hypodermic needle into the IO foramen might result in intravascular puncture and injection, hematoma formation, nerve damage or intraneural injection (VISCASILLAS et al., 2013). To avoid such complications, the stylet was introduced only for a few millimeters into the IO foramen and the catheter was then advanced alone, with the stylet held in place. Although, this methodology appears to be safer, it may result in kinking of the catheter when it is advanced. One alternative technique described in dog cadavers is to withdraw the stylet a few millimeters after introducing into the IO foramen and then advance the stylet and catheter together toward the maxillary nerve (VISCASILLAS et al., 2013).

It has been reported that 0.20 to $0.25 \mathrm{~mL}$ of anesthetic solution per site of injection is necessary to accomplish locoregional anesthetic techniques in the oral cavity of dogs and cats weighing 1 to $6 \mathrm{~kg}$ (BECKMAN, 2006). In the present study, the veterinarians were unaware of the weight of the cats but it is likely that all cats were between 1 and $6 \mathrm{~kg}$. Therefore, a single volume of $0.2 \mathrm{~mL}$ methylene blue dye was used for all injections and this volume is within the recommended range (BECKMAN, 2006).
In an in vitro study performed with sciatic nerves of frogs, when a length of $6 \mathrm{~mm}$ or greater of the nerve was in contact with lidocaine, conduction blockade was observed (RAYMOND et al., 1989). Based on the concept that at least $6 \mathrm{~mm}$ of nerve length should be exposed to local anesthetic to attain anesthetic blockade, an ideal score was assigned when staining of $\geq 6 \mathrm{~mm}$ of the maxillary nerve was achieved. A similar scale has been used to access staining of the maxillary nerve in dogs (VISCASILLAS et al., 2013).

The main complication of the technique observed in this study was staining of the cornea and sclera on the same side that the IO injection was performed. This finding may have resulted from inadequate technique and deposition of methylene blue dye in close proximity to the eye globe or migration of dye from the place of injection. Other macroscopically observed events reported in previous studies, such as intraneural or intravascular injection and damage to the peribulbar tissue, were not evidenced in the present study (GROSS et al., 2000; PERRY et al., 2015). However, such complications might be difficult to observe in a cadaver study if histopathology or MRI was not performed. The anesthetist should be aware of the close proximity between the maxillary nerve and the eye globe in cats and has to be careful to avoid damage to the ocular globe when performing a maxillary nerve block by either approach.

This study has some limitations. First, the time elapsed from death until the experiments were performed could not be standardized. In most cases, the experiments were performed within 2 days after the death. However, in a few occasions, over 5 days were elapsed. Prolonged storing under refrigeration could impair the tissue and cell integrity, even when refrigerated, that could have influenced our results in both groups. Second, injection pressure was not measured and 
resistance to injection was subjectively evaluated by the veterinarians performing the experiments. In one study, it has been reported that perception of appropriate resistance to injection may vary widely and may also be influenced by needle design (CLAUDIO et al., 2004). Therefore, intraneural injection, kinking or partial occlusion of the catheter can not be excluded in the present study.

\section{CONCLUSION}

Results of this study do not support the IO approach to perform a maxillary nerve block in cats. A greater accuracy of dye placement on the maxillary nerve was observed after the SBZ approach. A variable accuracy may exist between different anesthetists suggesting that professional experience may play a role in the success rate when performing a maxillary nerve block. Further studies are warranted to determine if similar findings will be observed in the clinical setting.

\section{BIOETHICS AND BIOSSECURITY COMMITTE APPROVAL}

Institutional Animal Use and Care Committee approval was not required because the cadavers were from cats admitted to the Veterinary Teaching Hospital, after natural death or euthanasia due to reasons unrelated to the study.

\section{REFERENCES}

BARDELL, D. et al. A cadaver study comparing two approaches to perform a maxillary nerve block in the horse. Equine Veterinary Journal, v.42, n.8, p.721-725, 2010. Available from: <http:// dx.doi.org/10.1111/j.2042-3306.2010.00080.x>. Accessed: Aug. 2. 2017. doi: 10.1111/j.2042-3306.2010.00080.x.

BECKER, D. E.; REED, K. L. Local anesthetics: Review of pharmacological considerations. Anesthesia Progress, v.59, n.2, p.90-102, 2012. Available from: <http://www.ncbi.nlm.nih.gov/pmc/ articles/PMC3403589/>. Accessed: Aug. 2, 2017. doi: 10.2344/00033006-59.2.90.

BECKMAN, B. W. Pathophysiology and management of surgical and chronic oral pain in dogs and cats. Journal of Veterinary Dentistry, v.23, n.1, p.50-60, 2006. Available from: $<$ https://doi.org/10.1177/0898756406 02300110>. Accessed: Aug. 2, 2017. doi: 10.1177/089875640602300110.

CLAUDIO, R. et al. Injection pressures by anesthesiologists during simulated peripheral nerve block. Regional Anesthesia and Pain Medicine, v.29, n.3, p.201-205, 2004. Available from: <https://www. ncbi.nlm.nih.gov/pubmed/?term=15138903>. Accessed: Nov. 16, 2017.

CREMER, J. et al. Assessment of maxillary and infraorbital nerve blockade for rhinoscopy in sevoflurane anesthetized dogs. Veterinary Anaesthesia and Analgesia, v.40, n.4, p.432-439, 2013. Available from: <http://dx.doi.org/10.1111/vaa.12032>. Accessed: Aug. 2, 2017. doi: 10.1111/vaa.12032.
DELlmANN, H. D.; MCClURE, R. C. Sistema nervoso do carnívoro. In: GETTY, R. Anatomia dos animais domésticos. 5. ed. Rio de Janeiro: Guanabara Koogan, 2008. p. 1569-1634.

DUKE, T. Local and regional anesthetic and analgesic techniques in the dog and cat: Part II, Infiltration and nerve blocks. The Canadian Veterinary Journal, v.41, n.12, p.949-952, 2000. Available from: $<$ http://www.ncbi.nlm.nih.gov/pmc/articles/PMC1476352/>. Accessed: Aug. 2, 2017.

FUTEMA, F. et al. A new brachial plexus block technique in dogs. Veterinary Anaesthesia and Analgesia, v.29, n.3, p.133-139, 2002. Available from: <http://dx.doi.org/10.1046/j.1467-2995.2002.00082. x>. Accessed: Aug. 2, 2017. doi: 10.1046/j.1467-2995.2002.00082.x.

GIOSO, M. A.; CARVALHO, V. G. G. Oral anatomy of the dog and cat in veterinary dentistry practice. The Veterinary Clinics of North America. Small Animal Practice, v.35, n.4, p.763-80, 2005. Available from: <https://doi.org/10.1016/j.cvsm.2004.10.003>. Accessed: Aug. 2, 2017. doi: 10.1016/j.cvsm.2004.10.003.

GROSS, M. E. et al. Regional anesthesia of the infraorbital and inferior alveolar nerves during noninvasive tooth pulp stimulation in halothane-anesthetized cats. American Journal of Veterinary Research, v.61, n.10, p.1245-1247, 2000. Available from: $<$ https:// doi.org/10.2460/ajvr.2000.61.1245>. Accessed: Aug. 2, 2017. doi: 10.2460/ajvr.2000.61.1245.

HUDSON, L. Nervous system and special sensory organs. In: HUDSON, L.C.; HAMILTON, W.P. Atlas of Feline Anatomy For Veterinarians. 2nd ed. Jackson: Teton NewMedia, 2010. p. 193-254.

KLAUMANN, P. R. Anestesia locorregional de nervos cranianos. In: OTERO, P. E.; KLAUMANN, P. R. Anestesia locorregional em pequenos animais. 1. ed. São Paulo: Roca, 2013. Cap.5, p.114-118.

PERALTA, S. et al. Canine and feline local anesthetic and analgesic techniques. In: GRIMM, K. A. et al. Veterinary Anesthesia and Analgesia: The Fifth Edition of Lumb and Jones. 5. ed. [s.1.] Wiley, 2015. p. $827-856$.

PERRY, R. et al. Globe penetration in a cat following maxillary nerve block for dental surgery. Journal of Feline Medicine and Surgery, v.17, n.1, p.66-72, 2015. Available from: <http://jfm. sagepub.com/content/17/1/66.abstract>. Accessed: Aug. 2, 2017. doi: $10.1177 / 1098612 X 14560101$.

RAYMOND, S. A. et al. The role of length of nerve exposed to local anesthetics in impulse blocking action. Anesthesia and Analgesia, v.68, n.5, p.563-570, 1989. Available from: $<$ https:// www.ncbi.nlm.nih.gov/pubmed/2785778>. Accessed: Aug. 2, 2017. doi: 10.1213/00000539-198905000-00004.

ROCHETTE, J. Regional anesthesia and analgesia for oral and dental procedures. Veterinary Clinics of North America: Small Animal Practice, v.35, n.4, p.1041-1058, 2005. Available from: <http://www.sciencedirect.com/ science/article/pii/S0195561605000240>. Accessed: Aug. 2, 2017. doi: 10.1016/j.cvsm.2005.02.004.

VISCASILLAS, J. et al. A cadaver study comparing two approaches for performing Maxillary Nerve Block in Dogs. Veterinary Anaesthesia and Analgesia, v.40, n.2, p.212-219, 2013. Available from: <http://onlinelibrary.wiley.com/doi/10.1111/ j.1467-2995.2012.00781.x/abstract>. Accessed: Aug. 2, 2017. doi: 10.1111/j.1467-2995.2012.00781.x. 